\title{
The Case for America's Continued Superpower Status
}

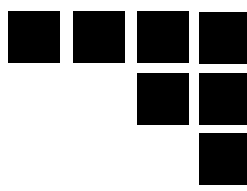

\section{Dennis Shiraev, Cornell 2012 \\ Arts and Sciences: Economics and Mathematics Majors \\ Grant Gibson, Georgetown 2012 \\ School of Foreign Service: International Relations Major}

Is America really in decline as a global superpower? We examine current arguments for America's economic decline and argue that a purely economic analysis is insufficient for evaluating a country's status as a global superpower. Our comprehensive definition of superpower incorporates military strength, internal stability, and the global attractiveness of a state's culture and ideology that it presents to the rest of the world. America is the only state fitting of this comprehensive definition of a superpower in the 21st century, while all other states frequently cited as emerging global powers fail to meet the criteria we lay out in this paper.

The Rationale Behind American Decline

Obama's presidency comes against a growing consensus that America is in the beginning phases of decline as the definitive global superpower. In 2009, GDP estimates and growth figures point to an increasingly diminished role of the United States in the global economy. ${ }^{1}$ As America faces what many consider to be the worst economic crisis since the Great Depression, many have also begun to question the credibility of the United States as the financial center of the modern world. Is there a case to be made for America's economic decline, and will America's reduced economic status in the $21 \mathrm{st}$ century compromise its role as the world's sole superpower?

To be sure, theories about the decline of America's power are as old as American power itself. During the 1960's, the Soviet Union's charge into space, economic growth, nuclear strengthening, and the increasing spread of communism around the world served as the bases for many theories on America's demise from security and economic perspectives. In light of American failures in Vietnam and the continued U.S.-Soviet arms race, the next decade saw more predictions of decline centered around national security. In the 1980's the focus shifted to economics as the world witnessed Japan's rapid economic development and the U.S. began showing signs of over-stretching. With the end of the
Cold War, there was talk of America's moral demise in a post bi-polar world that no longer had single superpower domination. ${ }^{2}$ None of these theories came to fruition, but that is no reason to dismiss more recent concerns without thorough examination.

The economic decline of the United States has been articulated in many arguments, the most prominent of which is that the United States has become a debtor nation, borrowing large sums of money from China as credit for continued economic and budgetary expansion. Chinese possession of large numbers of American T-bills has been cited as a major threat to economic security. Another oft-cited sign of decline has been America's industrial decline, as other nations begin to supplant America's productive role in the world industrial market. Needless to say, the economic concerns confronting the United States are considerable. ${ }^{3}$

There are also more normative arguments. In his Foreign Affairs article, even though he makes clear that the United States is not suffering from internal economic deterioration and will probably maintain its dominant share of the global economic pie, Fareed Zakaria makes the case that the United States will have to eventually accept a diminished global role as a result of the economic rise of the rest. "The rest that are rising are embracing markets, democratic 
government (of some form or another) and greater openness and transparency. It might be a world in which the United States takes up less space, but it is one in which American ideas and ideals are overwhelmingly dominant." Zakaria also points out that the United States' role in global finance is shrinking, with the rising states of Asia and even the established states of the Eurozone playing increasingly important roles in global finance and witnessing a faster overall growth of financial stock.

The recent financial crisis has only strengthened arguments about America's financial decline, adding the questionable future of free-market capitalism into the mix. Resulting from tangible financial losses as well as the loss of financial credibility and confidence, some believe that the global roles of the United States and the European states will shrink in tandem with those countries' economies and financial sectors. ${ }^{5}$

\section{The 21 st Century is Different}

We do not wish to, by any means, dismiss the importance of economics in international relations or global politics, but rather to reconsider the significance of economics as a measuring stick for how we conceive superpowers. As the world progresses into the 21 st century, a purely onedimensional economic evaluation of a state's superpower status has become increasingly insufficient.

One can easily see that, on the most basic level, that a country's economic size and importance as a center of global finance does not necessarily correlate with its importance in international affairs. Economic size is usually measured in GDP, or Gross Domestic Product, which is equal to the total value of domestic consumption, investment, government expenditure, and net exports. Japan, which ranks second in total nominal GDP, holds very little sway in international politics, while countries with increasing regional influence like Iran and Venezuela have economies more than ten times smaller than Japan, by most estimates. $^{6}$

Recent surveys of the world's top financial centers also blur the connection between the importance of a state's financial sector and its influence in global affairs. In a 2008 survey of the world's top financial centers, one will find the Swiss cities of Geneva and Zurich ranked seventh and fifth, respectively. ${ }^{7}$ Two things appear clear: having top financial centers within a state's borders does not qualify it as a superpower (Switzerland), nor does the absence of a top financial center disqualify a country from having prominence as a regional or global power (ex. Russia, India, Venezuela, Brazil, France, Saudi Arabia, Iran).

The increasing pace of globalization has also complicated the importance of a country's GDP figures as a determinant of its influence in international affairs. The rise of the United States as a global superpower came about mainly as a result of the long standing American traditions of openness and innovation. The United States owes much of its historical ascent to its ability to attract the ingenuity of vastly diversegroups of peopleand to channel that human capital into industrial innovation and economic dynamism. ${ }^{8}$ World War One gave America an opportunity to showcase its might as a regional power, and after the Second World War left most of Europe in complete ruin, the balance of power shifted westward and America established itself as a premiere global superpower. But, historical circumstance aside, what made America into the economic giant that it is today? We maintain that it was a distinctly American commitment to innovation, industrialization, open trade and liberalized economics that shot America onto the global scene and kept it there for the remainder of the 20th century. This is where America derived much of its original advantage over other countries, but as more and more countries embrace democratic governments, open trade policies and market-oriented economies, it is no wonder that America's share of the global 
GDP pie will diminish to some extent. Zakaria provides an elaboration of this concept: "Over the last 20 years, globalization has been gaining breadth and depth. More countries are making goods, communications technology has been leveling the playing field, capital has been free to move across the world-and the United States has benefited massively from these trends." In many respects, the world has become more of a leveled playing field where economic imbalances are likely to have less pronouncement. Pure GDP comparisons are no longer sufficient.

\section{Towards a More Comprehensive Definition}

A more comprehensive definition of superpower is needed for the increasingly globalized world of the 21st century. We stress at least three factors: the importance of military capabilities (along with the concomitant influences of these capabilities), internal stability, and the global attractiveness of a state's culture and ideology. The intention here is not to overlook economics-we have already shown why a purely economic evaluation is insufficient, and all of these three criteria are dependent on the existence of a functional economy. Of all of today's powers, the United States is the only one that possesses significant strength in all three categories.

In the 21st century, a state's military strength will remain relevant for its sway in international affairs. But many would argue

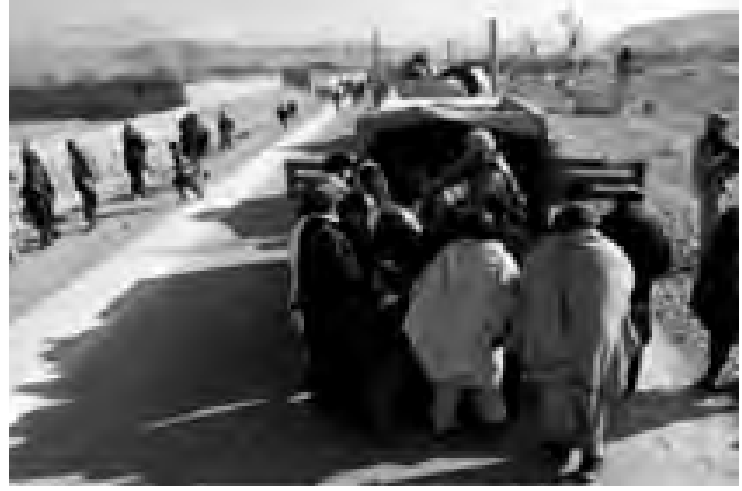

Local villagers in Afganistan receive aid from US military forces that, because of the decreasing fear of direct attack between established nation states, military force is no longer as relevant in the 21 st century. Moreover, many economic and ecological goals of growing importance are not achievable through military means. ${ }^{9}$ To a certain extent, we agree that pure military force and second-strike capabilities are perhaps less important than they were before, but the military aspect of state's superpower status cannot be overlooked. The ability to project power around the world is of paramount importance to any superpower, and, as recent operationsin Panama,Haiti,Somalia, thePersian Gulf, and Afghanistan show, coercion remains a strong force in international diplomacy. The first element of military strength is a simple relative advantage over other states. The ability to easily deter and defeat potential threats and enemies will always be a top military objective for any superpower. Additionally, defense and security obligations are a way for a potential superpower to expand its power. By guaranteeing the security of other states, the superpower forces protected countries to buy into the international system that serves the best interest of their protector. Training missions are another way of extending geopolitical power through military means. Military training enhances the military capabilities of allies while building important cross-military ties that serve to strengthen future relations. Finally, military arms sales are invaluable for international influence. Besides strengthening the diplomatic relationship between a superpower and an ally or potential ally, arms sales symbolize a commitment and high level of trust between the buyer and the seller. Buyer states trust that these weapons will not be used against its interests while the seller state trusts the buyer to both help supply the spare parts and the training for the weapons.

The U.S. is the global military leader on both of these fronts. The size of the United States' economy also allows it to outspend the rest of the world in military expenditures while 
utilizing less than $5 \%$ of its GDP on military spending. ${ }^{10}$ The United States has utilized these expenditures to create a force at least twenty years ahead of its closest competitors. The money invested in the late eighties and early nineties gave birth to a generation of military hardware that has yet to be matched by any country. The American ability to project power is also unrivaled. During the first Persian Gulf War, American generals were frustrated by their inability to build up substantial forces in Kuwait quickly. Since then, the United States has greatly expanded its ability to quickly deploy forces anywhere in the world on short notice. Aircraft carriers, amphibious assault ships, ballistic submarines, and long-range bombers give the United States the unprecedented ability to rapidly project force anywhere in the world. American military power is an especially potent tool because it is one of the most fungible forms of power. Fungibility is the ability of one form of power to influence other realms of influence. ${ }^{11}$ Military power is highly fungible because it influences diplomatic relations and political decisions. American military power not only allows dominance in battle but also holds much influence over other areas of influence.

The second criterion for a superpower, one greatly overlooked by those who argue for the decline of America and the rise of other regional powers, is a state's internal stability. As far as it concerns a superpower's leverage and maneuverability in international relations, internal stability is crucial because a state must beabletomakeforeign policydecisionswithout the looming threat of its citizens revolting against and taking over the government. This is by no means an endorsement of governments not being held accountable to the people who elect them. Quite the opposite: the state must be accountable, but only through welldefined and respected means of electing, changing, and transferring power. Internal stability also concerns societal stability, ethnic harmony, and the absence of destabilizing separatist movements. It is not our intention here to overlook deficiencies and inequalities in American society, but we do argue that American society and the American institution of democracy are and will remain stable. We need not look further than the last fifteen years of American history to see just how stable our institutions really are. In this period, Americans witnessed presidential impeachment hearings, an historic 2000 election that challenged the very roots of our legal processes, a domestic terrorist attack that cost the lives of more than 2,000 citizens, and two foreign wars. And yet, the fabric of American society held together, and the system continued to work. The election of Barack Obama as the forty forth President of the United States is just another indication of the societal progress that America has made and will continue to make in the future.

Although our first two superpower criteria are more fitting of a realist perspective, we cannot avoid taking a neoliberal perspective in advocating the importance of a state's culture and ideology that it presents to the rest of the world. Joseph Nye's concept of soft power comes into play here. A nation, by pure virtue of its identity, can attract nations to its influence and expand its relative power in the world. This identity is composed of a nation's values and culture. A sellable culture and ideology is necessary for a superpower not just for material purposes such as attracting immigrantsbutalsofortheimmaterial objective of creating a positive global perception. If we integrate a constructivist standpoint-which maintains that the structures of international relations among states are determined by shared ideas instead of material forces-into our comprehensive definition of superpower, then the global perception of a superpower's culture and ideology is just as important as the superpower's military might and internal stability. ${ }^{12}$ We cannot speak for the peoples of the world, nor can we make a claim about how citizens of different states perceive the United States. But we believe we can make a case for the culture and ideological image of America that most Americans would like to project to the 
rest of the world: one characterized by limitless individual possibility and a commitment to democracy and capitalism. The New York Yankees, Coca-Cola, and McDonald's arches are perhaps the greatest symbols of the global appeal of American culture and America's superpower status. Critics of this constructivist view would question the value of soft power. As an answer to this, we would point to Nazi Germany as a nation that possessed the more traditional means of power, but didn't have a culture that attracted other nations to its side. Only through force was German hegemony maintained in Central Europe. Had Germany held cultural and ideological sway over its Central European allies, then its allies would not have defected over to the Allied side at the first opportunity. America, on the other hand, has very strong allies because it holds a tremendous amount of cultural influence. This is the mechanism through which an attractive culture and ideology translates into international influence.

\section{The Case Against The Rest}

The United States is not simply fitting of this comprehensive definition of superpower-it is the only state that is and will be fitting of a unipolar superpower status in the foreseeable future. No other state or region of the world is fitting of this denotation.

The Russian Federation has been mentioned by Zakaria as a country on the rise, ascending to its old status as a world leader and power. However, the Russian Federation does not come close to meeting the definition of a superpower that has been set forth in this paper. Militarily, Russia remains a shadow of its former self. Neglect has left large stocks of weapons useless and a counterproductive, nepotistic and cruel culture has emerged within the military community. Additionally, the Russian military never fully designed and produced a set of weaponry comparable in quality to weaponry produced by the U.S in the eighties.

As for internal stability, the Russian
Federation is in a bad situation. The Caucus republics have grown more and more unstable since the fall of the Soviet Union. Only the presence of the military and heavily armed internal security troops maintains order in these regions. Separatist rebels have found common cause with Al-Qaeda and have become part of an international terrorist network with vast resources. These networks have already struck within Russia with great effect. Partly as a consequence of the increasingly authoritarian government-which is moving further and further away from even the most imaginative conceptions of a democratic state-there is little respect for property rights. Organized crime and corruption have corroded the average individual's ability to hold and invest in property. ${ }^{13}$

Russia ultimately lacks something that it possessed with great strength throughout the Cold War: an ideology with universal appeal. Communism was at times very popular in countries crucial to Russian national security interests, but Russian nationalism is no substitute for communism and does not give the Russian Federation the amount of international leverage possessed by the Soviet Union. Russia will only be relegated to the role of a second-rate power for the foreseeable future.

India, with its rapid growth rate and possession of nuclear weapons might also be described as a rising power capable of assuming a certain level of global leadership. In terms of economic growth, which is necessary for bringing millions of Indian citizens out of poverty, India's long term economic expansion will be hampered by several long-term economic maladies. The socialist legacy of a large bureaucracy hurts growth while a lack of infrastructure will severely limit Indian growth until rectified.

Militarily, India will be limited by the need to defend itself from a hostile Pakistan and an increasingly powerful China. These defensive considerations will forever limit India's ability to project military force beyond 


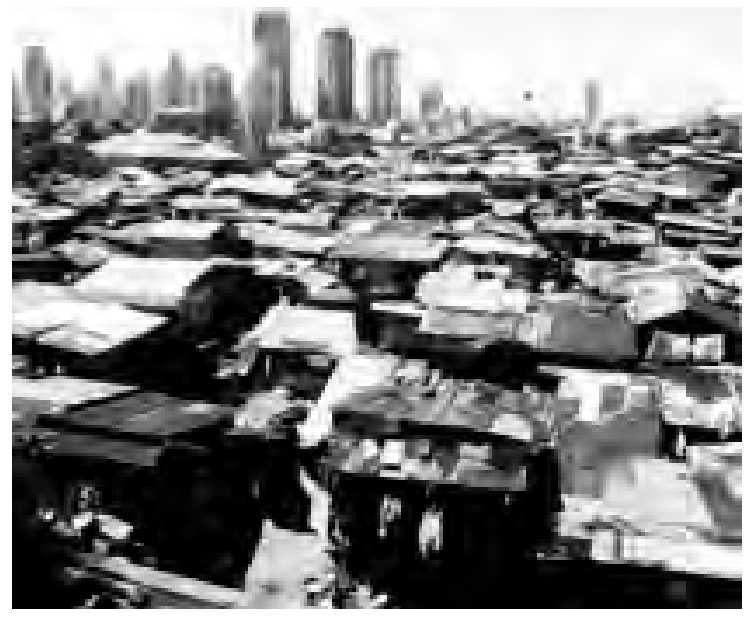

India's sprawling slums are one of the challenges facing India's rise as a superpower

its own borders. Internally, rising Hindu nationalism has added an element of instability to an already volatile domestic scene. Ethnic and religious strife threatens to destabilize regions within India as well as upset the already delicate political balance. If marginalization continues, ethnic and religious minorities may feel compelled to resort to violence to achieve their goals. Finally, although a democracy, India has never really attempted to embrace or export an ideology with broad appeal. The rising Hindu nationalism will only further corrode India's ability to utilize its own soft power. These limitations will undoubtedly hamper India's power for the foreseeable future.

Brazil has in recent years been cited as a power rising in South America that will challenge American hegemony in the Americas. However, Brazil must overcome a myriad of obstacles before it can even begin to be considered a world power, let alone a superpower. Its current growth rate is about five percent but it has yet to develop any solid infrastructure. ${ }^{14}$ Brazil has little ability to project military power beyond its own borders because Brazilian military operations will be confined for the next several decades to South America and to peacekeeping operations. As for internal stability, Brazil is suffering from a crime wave that shows no sign of abetting. Gangs control large swathes of Brasilia and are spreading throughout the country. The drug trade remains rampant, with more groups operating in Brazil's jungle regions, and Brazil's population consuming the second-highest level of cocaine in the Americas. Organized crime and violence associated with the drug trade continues to be a destabilizing threat. As for ideology, Brazil has yet to establish a strong democratic tradition, having only recently emerged from a military dictatorship in 1985. Currently, Brazil is suffering from a great financial crunch that threatens to economically destabilize the country for years to come. Brazil has a long way to go before it can be considered a major power.

The European Union has been described by Mark Leonard as possessing the traits befitting a rising power. Without a doubt, the European Union has a huge share of the world's economic might. However, economic might and influence is the only area in which the EU has substantial clout. Attempts to create a united military command have barely gotten off of the ground, with states reluctant to cede any authority over military affairs. The much-touted rapid reaction force is in actuality only a listing of units that could be made readily available in the event of a crisis. After joining the European Union, Eastern European states were encouraged to actually reduce their military in order to fund services and promote stability. Hardly any Western European countries maintain their defense spending above $2 \%$ of their GDP. ${ }^{15}$ As a result, many European militaries are completely unprepared to mount large independent operations. The European internal political situation is not conducive to quick decision making or even consensus building. This is evidenced by the repeated failure of the passage of the European Constitution. Quick decision making is a luxury not enjoyed by the European Union. The lack of a united national identity makes internal stability a huge problem for the European Union. Risky overseas ventures will never meet the required unanimous consensus required for collective 
action.

It is hard to make a case that the EU has a common culture that is recognizable on the world stage. Additionally, the recent economic crisis has exacerbated tensions within the European Union, with the Eastern European states clamoring for aid that the Western states wish not to give. The frictions exposed by this financial crisis betray the fact that the European Union is incapable of assuming great authority in the international stage. Although the EU may have the potential to act as a world power on the geopolitical stage, it is certainly unable to summon the high threshold of support it needs to do so. It is also worth noting that the EU and the U.S have many goals and interests in common, which curbs European motivation to participate in politics on a greater level with more responsibilities.

China is the state most cited as the rising superpower on the international stage. Its double digit growth rate has impressed many economic analysts while diplomatic success has convinced the world of Chinese foreignpolicy prowess. However, China possesses several glaring weaknesses overlooked in most analyses. First and foremost, the Chinese economy has yet to fully tap into its potentially lucrative but unevenly developed domestic market. Additionally, there are a myriad of state run enterprises that were never privatized, reducing the long-term efficiency of the economy. A weak banking system leaves little protection in times of economic peril. Economic success has also led to the rise of a middle class. This class has unique economic and political needs such as social mobility and certain levels of individual freedom. We can only speculate, but the Chinese government may face problems when giving into the demands of this growing class.

The Chinese have yet to develop a military force capable of projecting overwhelming force on a regional basis. Granted, construction has begun on their new navy, but it will be many years before they even begin to develop a blue-water capacity. ${ }^{16}$
While in possession of some high-quality equipment in certain units, the majority of the People's Liberation Army is still equipped with weapons of inferior quality.

Throughout recent history China has only intervened in its immediate region, casting doubt as to whether or not China would even desire to shoulder the responsibilities of a great power. More importantly, the area where the China's power suffers the most is internal instability. The abandonment of pure, messianic Communism thirty years ago has forced the Chinese to sell a new ideology to their people. This ideology is essentially Han Chinese nationalism with the promise of rapid economic growth. This strategy has so far proven useful, but may prove to be detrimental to long-term security. Han nationalism is a potential powder keg. Failure to meet the expectations of an increasingly nationalistic population could lead to internal destabilization and riots. The uneven distribution of wealth has already led to simmering riots in the country's interior. Further harming stability is the fact that minority populations within China have also become increasingly marginalized, leading some of them to turn to violent resistance against the government. Finally, the promise of economic growth makes support for the government contingent on economic success. This potential for internal instability prevents the Chinese government from taking substantial foreign policy risks. If the Chinese government experienced a major foreign policy failure, it might see a devastating backlash of public opinion. In terms of having an exportable ideology, the abandonment of communism has also left nationalistic China ideologically weakened, limiting its soft influence outside of its own borders.

\section{Conclusion}

For the time being the world will remain unipolar with the United States as the sole global superpower, but will it always remain so? It is highly unlikely that the United States' 
military superiority or internal stability will diminish in the foreseeable future, but the global perception of the United States is much more subject to change. If the United States is to remain the sole global superpower, it must continue to reify the cultural and political principles that made it a global superpower. It must, in a sense, continue to be perceived as the global standard of progress and opportunity, as well as might and influence. The election of Barack Obama, the first African-American president, is a step in the right direction. But the way in which the United States reacts to the financial crisis may be the most important test for Americans. We believe that America must take leadership in leading the world out of the current financial crisis - the United States must act in such a way to save the free market institutions that have driven so much global growth in the past centuries. If the United States fails to take leadership in the global economic recovery process and responds with increased levels of protectionism, it would harm the global attractiveness of its values and ideology and experience a real contraction of its influence in global politics. If America seizes the opportunity to lead the global economy out of the current crisis, this would be the newest reaffirmation of its status as the sole global superpower.

Acknowledgements: We wish to thank the following professors and students for their valuable contributions and commentary: Peter J. Katzenstein, Ambassador H. Allen Holmes, Eric B. Shiraev, Jake Bean, Chris Eng, Michael Jameson, Heide Celeghin, and Ryan Woo.

\section{Endnotes:}

1 "China may overtake US by 2025, but Vietnam may be fastest growing of emerging economies." PriceWaterHouseCoopers. 4 March 2008. http:// www.pwc.com/extweb/ncpressrelease.nsf/docid/B99EDBB955503B33852573FE005678F5

2 Shiraev, Eric, and Vlad Zubok. International Relations in an Uncertain World. New York: McGraw Hill, forthcoming 2009.

3 Ferguson, Niall. The Ascent of Money: A Financial History of the World. The Penguin Press, New York, 2008.

Zakaria, Fareed. "The Future of American Power." Foreign Affairs May/June 2008: 18-43.

Altman, Roger C. "The Great Crash, 2008." Foreign Affairs January/February 2009: 2-14.

"CIA World Factbook." 8 January 2009. <https://www.cia.gov/library/publications/the-world-factbook/geos/ja.html>

"The World's Top Financial Centers." Business Week. March 2008. 8 January 2009. <http://www.businessweek.com/globalbiz/content/mar2008/ gb2008035 012894.htm?campaign id=rss topStories>

$8{ }^{7}$ Chua, Amy. Day of Empire. New York: Doubleday, 2007.

9 Keohane, Robert O., and Joseph S. Nye. From Power and Interdependence: World Politics in Transition. Addison-Wesley Educational Publishers, 1989.

10 "CIA World Factbook." 8 January 2009. <https://www.cia.gov/library/publications/the-world-factbook/geos/us.html>

11 Art, Robert J., and Robert Jervis. International Politics: Enduring Concepts and Contemporary Issues. Pearson Education, 2009.

12 Wendt, Alexander. Social Theory of International Politics. Cabridge: Cambridge University Press, 1999.

13 Nye, Joseph. Soft Power: The Means to Success in Modern Politics. New York: Perseus Book Groups, 2004.

14 Greenspan, Alan. The Age of Turbulence: Adventures in a New World. New York: Penguin Group, 2007.

15 "Trends in European Defense Spending, 2001-2006." Center for Strategic and International Studies. April 2008. 8 January 2009 <http://www.Csis. org/media/csis/pubs/080424-chao-europeandefense.pdf>

16 "Warship Modernization." GlobalSecurity.org. 8 January 2009. < http://www.globalsecurity.org/military/world/china/plan-mod.htm>

Staff Sgt. Davis, Tiffani L. "Local villagers recieve humanitarian aid." 14 Jan 2009. US Army. 2 April 2009. <http://www.army.mil/yearinphotos/2008/>

"Rooftops of Indias Slums." Concurring Opinions. 4 April 2009. < www.concurringopinions.com/.../> 